\title{
Interactions Between Lower- and Higher-Level Processing when Reading in a Second Language: An Eye-Tracking Study
}

\author{
Annina K. Hessel and Sascha Schroeder \\ Department of Educational Psychology, University of Goettingen
}

The current manuscript is the postprint of a paper accepted for publication with Discourse Processes (doi: 10.1080/0163853X.2020.1833673)

\begin{abstract}
Author Note:
Correspondences concerning this article should be addressed to Annina K. Hessel, University of Goettingen, Waldweg 26, 37073 Göttingen, Germany; e-mail: annina.hessel@ psych.unigoettingen.de; Twitter: @AnninaHessel
\end{abstract}




\begin{abstract}
This experiment investigated interactions between lower- and higher-level processing when reading in a second language (L2). We conducted an eye-tracking experiment with the within-subject manipulation inconsistency (to tap higher-level coherencebuilding) crossed with a within-subject manipulation of word processing difficulty (to alter the ease of lower-level processing), both manipulated on the text level. Sixty-three L2 learners read 48 short expository texts containing inconsistencies created through mismatches between pre-targets such as soya and targets such as corn, or consistent controls. Word processing difficulty was manipulated by inserting either shorter and higher-frequency words such as often, or longer and lower-frequency words such as increasingly. We found evidence of interactions between lower-level word processing difficulty and higher-level coherence-building, as revealed by reduced inconsistency go-past durations and rereading in the difficult condition. This effect did not, however, extend to targeted regressions into inconsistent information. Our findings provide first experimental evidence for online interactions between lower-level word processing and higher-level coherence-building.
\end{abstract}

Key words: reading, lower-level processing, higher-level processing, eye movements, second language, inconsistency, processing bottleneck 


\section{Interactions Between Lower- and Higher-Level Processing when Reading in a Second Language: An Eye-tracking Study}

Across areas of life, people get important information from reading texts - be it in education, work, or simply at the bus stop. Increasingly so, people read these texts not only in their first but also in their second language. For skilled readers, reading words in both their first and second language is so well-trained that it becomes automatic, as famously demonstrated in the Stroop task (Braet, Noppe, Wagemans, \& Op de Beeck, 2011; Jensen \& Rohwer, 1966). However, texts are more than a list of words - words form sentences, and sentences build up on each other to convey an overall message. Comprehending a text's message requires a reader to not only understand each word, but to also recognize and draw links between sentences - that is, comprehension requires higher-level processing (Castles, Rastle, \& Nation, 2018). Successful higherlevel processing relies on both bottom-up, automatic processes - such as visual word recognition and spreading activation from a word to its orthographic or semantic neighbors - and top-down, reader-initiated processes - such as actively inferring word meanings from their textual context (van den Broek \& Helder, 2017). While bottom-up processing clearly shows in lower-level word recognition and top-down processing shows in far-from-the-text processes such as looking up unknown words, bottom-up and top-down processing are much harder to disentangle in higher-level reading processing that is closer to the text, such as repairing coherence breaks (van den Broek \& Helder, 2017). It has been suggested that such close-to-the-text higher-level processing is strongly influenced by the efficiency of lower-level word processing (Stafura \& Perfetti, 2014), but such interactions between lower- and higher-level processing are likely complex and far from fully understood. In the present study, we explore these 
exact interactions by testing how changes in lower-level word processing influence readers' higher-level coherence-building.

A common way to test online or moment-to-moment coherence-building during reading is the inconsistency paradigm. Readers are presented with texts containing inconsistent information (e.g. a kitten that barks) while their eye movements are monitored (Hessel, Nation, \& Murphy, 2020). Coherence-building in the face of inconsistencies would then show in the reader noticing and re-analyzing the inconsistency. Since eye movements indicate where the attention goes during reading, both noticing and repair will be reflected in the eye movement record. Generally, higher-level coherence-building shows in increased rereading of inconsistent compared to consistent information (Connor et al., 2015; Hessel et al., 2020; Joseph et al., 2008) and, depending on reader skills and type of inconsistency, in gaze duration (or the time spent first reading a word) and go-past duration (or the time spent from first reading a word to exiting it to the right) (Joseph et al., 2008; Rayner, Warren, Juhasz, \& Liversedge, 2004), as found in children (Connor et al., 2015; Eilers, Tiffin-Richards, \& Schroeder, 2018; Kim, Vorstius, \& Radach, 2018; Kinnunen \& Vauras, 1995; van der Schoot, Reijntjes, \& van Lieshout, 2012; Vorstius, Radach, Mayer, \& Lonigan, 2013; Zabrucky \& Ratner, 1989) and adults (Rayner et al., 2004; Weiss, Kretzschmar, Schlesewsky, Bornkessel-Schlesewsky, \& Staub, 2018). Importantly, increased rereading of inconsistent information reflects higher-level processes that are necessary for coherence-building and successful comprehension. The key role of rereading in comprehension is supported by evidence that comprehension suffers when rereading is made impossible through masked text (Schotter, Tran, \& Rayner, 2014). Rereading behavior on inconsistent compared to consistent target words is thus a good indicator of readers' ongoing coherence-building. 
The key question is how the higher-level processing of inconsistencies interacts with lower-level processing. First insights come from studies comparing inconsistency processing between readers who read more or less fluently due to varying language skills (Connor et al., 2015; Eilers et al., 2018; Hessel et al., 2020). Readers with stronger word knowledge and higher reading fluency adapt their rereading more strongly to inconsistent vis-à-vis consistent target words than less fluent readers, indicating that efficient lower-level word processing goes hand in hand with equally efficient coherence-building. Specifically, this shows in the fast reading of consistent information as well as increased regressions directly into inconsistent information (Eilers et al., 2018; Hessel et al., 2020). This suggests that fluent lower-level word processing goes with both fluent higher-level processing (where possible) and targeted additional effort (where necessary). Similar interactions are also described in the Reading Systems Framework, a theory which places efficient word processing at the center of higher-level comprehension (Perfetti \& Stafura, 2014). In online recordings of event-related potentials when people read words that extend previously mentioned events (such as when rain adds information on an aforementioned storm), Perfetti and colleagues found that slow word readers showed delayed and qualitatively different integration processes compared to skilled readers, indicating that word processing influences both the speed and the composition of higher-level processes (Perfetti, Yang, \& Schmalhofer, 2008; Stafura \& Perfetti, 2014). The idea is that when too much of a reader's processing capacities are taken up by lower-level processes, their ability to engage in higher-level processing is limited. This mechanism has been described as a bottleneck of reading in that a low efficiency of lower-level processes can reduce or even prevent higher-level text processing (Perfetti, 1985). The same bottleneck could explain the both fluent and targeted inconsistency rereading of skilled readers. 
Effortful lower-level processing seems even more influential for higher-level processing when reading in the second language (L2) as opposed to the first language (L1). Offline studies looking at L2 expository text reading find a key effect of highly developed word knowledge and reading comprehension on higher-level text comprehension, both for children and adults who are reading in their L2 (see for instance Block, 1992; Horiba, 2012; Hosoda, 2016; Raudszus, Segers, \& Verhoeven, 2019). Online eye-tracking studies show that the reading process in an L2 is generally characterized by more effortful processing, showing in longer reading times and more regressions (Cop, Drieghe, \& Duyck, 2015). Importantly, L2 reading also differs from L1 reading in sentence and higher-level processing, as evident in L2 readers being less sensitive to syntactic violations (Lim \& Christianson, 2014) and less efficient in the revision of previously made inferences (Pérez \& Bajo, 2019). While part of these differences may be explained by cross-linguistic interferences (Libben \& Titone, 2009), L1 and L2 reading differences seem to largely result from L1 readers' oftentimes weaker syntactic and lexical knowledge (Hopp, 2016b). This is support by studies that document strong relationships between L2 learners' language skills and their online reading processing (Lim \& Christianson, 2014; van den Bosch, Segers, \& Verhoeven, 2018; Whitford \& Titone, 2012), and those showing that processing becomes native-like as L2 proficiency increases (Hopp, 2016a; Pérez \& Bajo, 2019).

In the aforementioned studies, effects of lower- on higher-level processing were found through correlations of online reading with individual differences in language proficiency tests. Correlational evidence by itself, however, is not an unambiguous test of interactions between word and higher-level processing. More and less skilled readers differ on more than one linguistic and cognitive dimension, many of which could cause the observed correlations (Castles et al., 2018). To really pinpoint an effect, a direct 
experimental test is needed where the factor of interest is varied by altering task demands within a subject (Hopp, 2016b; McDonald, 2006). For example, Hopp recorded L2 learners' reading times on English object or subject clefts that either contained high- or low-frequency verbs (e.g., scared or horrified) - thereby making lexical access either easier (in the case of scared) or harder (by inserting horrified, Hopp, 2016b). Low-frequency verbs delayed L2 learners' processing of syntactic complexity, indicating that the efficiency of lower-level word processing interacted with higher-level syntactic processing. Importantly, this relationship was more pronounced for L2 than for L1 readers, suggesting that lower-level processing plays a more prominent role in L2 higher-level reading. In a similar study, McDonald experimentally tested the effect of working me mory and decoding on L2 learners' syntactic processing by comparing L2 and L1 learners' grammaticality judgement with and without experimentally raised working memory and decoding load (2006). She found that under higher memory and decoding load, L1 learners' syntactic processing resembled that of late L2 learners who scored low on L2 working memory and decoding, suggesting that lower-level processing difficulties had led to the less efficient L2 syntactic processing. Importantly, both Hopp's and McDonald's studies demonstrate that experimental manipulations can serve to pinpoint the driving force behind difficulties in L2 language processing. So far, however, no experimental study has tested the effects of a manipulation of lower-level word processing on L2 higher-level coherence-building.

To test interactions between lower-level word processing and coherence building experimentally, we thus decided to create a task where inconsistency was crossed with word processing difficulty. As it is customary to only insert one inconsistency in each text, one key decision in our study design was whether to use fewer but longer and more naturalistic stimuli texts for the sake of ecological validity 
(cf. for instance Albrecht \& O’Brien, 1993; Edward J. O’Brien \& Albrecht, 1992; Edward J. O’Brien, Cook, \& Guéraud, 2010; Zwaan \& Madden, 2004) or to create shorter but more numerous passages for the sake of multiple repeated measurements that yield a higher-powered study (Eilers et al., 2018; Joseph et al., 2008; Rayner et al., 2004; Weiss et al., 2018; Zabrucky \& Ratner, 1989). As our goal was to probe whether inconsistency and word processing difficulty would interact or not, a question that can only be answered using a sufficiently high-powered study, we chose to prepare a larger number of shorter texts in order to ensure high enough power to reliably detect the predicted interaction. For each text, we created two versions where either easier or harder words surrounded the inconsistent information. To alter word processing difficulty or the ease and speed of word retrieval across the texts, we relied on two key determinants of lexical access, namely, word length and frequency. Less frequent (Inhoff \& Rayner, 1986; Joseph, Nation, \& Liversedge, 2013; Juhasz \& Rayner, 2006; Tiffin-Richards \& Schroeder, 2015) and longer words are known to be recognized more slowly and known less well (Gagl, Hawelka, \& Wimmer, 2015; Joseph, Liversedge, Blythe, White, \& Rayner, 2009; Tiffin-Richards \& Schroeder, 2015). Context words were thus designed to be either short and frequent or long and infrequent - creating both an easy and a difficult condition for lower-level word processing. With all participants reading stories in easy and difficult as well as in consistent and inconsistent conditions, we can experimentally test interactions between lower-level word processing difficulty and higher-level coherence building.

\section{The present study}

We ask whether lower-level word processing interacts with higher-level coherence building when reading inconsistencies in an L2. In our study, adult L2 learners read short expository text passages while their eye movements were monitored. The texts 
were manipulated following a 2 X 2 design, containing the factors word processing difficulty (difficult vs. easy) and inconsistency (consistent vs. inconsistent). Both factors were manipulated within-subject, on the text-level.

We expected inconsistent targets to be processed more slowly and more selectively than consistent targets, particularly in rereading. We also expected readers to spend more time reading difficult than easy context words, both during gaze duration and rereading. In line with the idea of a bottleneck in reading that can be triggered by less efficient word processing, we predicted that inconsistency processing would interact with word processing difficulty, as visible in a reduced inconsistency effect in texts containing difficult words. We expected this reduced inconsistency effect to stem from longer rereading times on consistent words and fewer regressions into inconsistent information in the difficult condition, indicating that high word processing difficulty goes with a reduced ability to target attention. Such an interaction would support the idea that lower-level processing interacts with higher-level coherence-building in L2 reading. If, however, word processing difficulty and inconsistency had independent effects on reading processing, this would indicate a limited or no interaction between the two processing levels.

\section{Materials and Methods}

\section{Participants}

Based on a simulation-based power calculation, we had planned to recruit $\mathrm{N}=60-65$ language learners to reach statistical power of $>0.80$ for our predicted effects (namely, the main effects of word processing difficulty on the gaze duration and rereading on difficulty manipulated words, and both the inconsistency main effect as well as its 
interaction with word processing difficulty on the rereading of inconsistency targets). We thus recruited sixty-seven German university students using the university-managed online database ORSEE. All participants gave their consent to take part in the study and were remunerated for their time either through experimental hours $(n=50)$ or a payment of 12 Euro $(n=17)$. Four participants did not finish the experiment due to technical problems or because they were unable to finish the task within the available timeframe (1.5 hours). The final sample thus comprised 63 participants $(n=34$ female, mean age of 23.6 years, $\mathrm{SD}=4.6$ ). All participants had normal or corrected-to-normal vision.

To describe the language background of our sample, we assessed key aspects of their English language ability and use (see Table 1 for an overview). English language ability was assessed as single word reading and vocabulary size. Single-word reading was tested using the second version of the Test of Word Reading Efficiency (TOWRE2, Torgesen, Rashotte, \& Wagner, 2012) where the participants read aloud lists of words or nonwords, and scores are calculated as the number of items read correctly within 45 seconds. Vocabulary size was measured using the LexTALE where the participants are presented with 60 English words and non-words and have to decide if each word is a real word or not (Lemhöfer \& Broersma, 2012). Scores are calculated as the percentage of correctly identified words minus errors on non-words. Based on the LexTALE norms (Lemhöfer \& Broersma, 2012), there was a range of English-language abilities in our sample, ranging from intermediate skills at B1 and lower $(n=9)$ to upper intermediate or B2 ( $\mathrm{n}=37)$ and highly-proficient $\mathrm{C} 1$ or C2 level speakers $(\mathrm{n}=17)$. Note, however, that these norm scores likely lack precision as the LexTALE's reliability in our sample was surprisingly low, with a split-half reliability of 0.21 compared to 0.81 in the LexTALE norming study (Lemhöfer \& Broersma, 2012). 
English language use was assessed in a guided interview with the experimenter based on our language background questionnaire (see Appendix A). In the first part of the questionnaire, participants are asked about their language learning history at home, at school and during stays abroad. In the second part, participants answer questions about their current language use in conversations or their media use. All participants reported to have learnt English either at primary or secondary school. Thirty-six subjects had also spent some time abroad, ranging from short stays of two weeks to extended stays of five years. Less than half of the participants in our sample used English regularly in conversations $(\mathrm{n}=30)$, but all participants used media in English, with most time with English spent when watching series or films, followed by reading books or papers and social media use (see Table 1).

[Table 1: near here]

\section{Materials and Procedure}

Reading task. Forty-eight 3- to 5-sentence texts were adapted from short educational texts found on online materials for language support (Word Generation, Using English, or TOEFL test preparation materials) and easy-language informational texts (BBC Bitesize). The texts were adapted so that they were of similar length (55 ( $\mathrm{SD}=6)$ words on average) and were suited for both the inconsistency and the word processing difficulty manipulation described below. The adapted texts were checked for acceptability by two native speakers of British English, with each speaker being asked to read half the texts and indicate any words, phrases or sentences that appeared ungrammatical or semantically anomalous. All identified passages were then rephrased and rechecked until the entirety of the reading task was judged to be acceptable. The texts cover a range of topics, including climate change, education, vegetarian diet, and pets. An example is shown in Table 2 (Appendix B contains a full list of stimuli). 
[Table 2: near here]

The inconsistency manipulation was created through a combination of pre-target and target words that were either the same words or inconsistent with one another. Pretargets were consistent with the surrounding text so that even in the inconsistent condition, the following target word was the first inconsistent word in the text (e.g. when soya appeared in a text that previously talked about corn). Eye movements were subsequently only analyzed for target words. This means that the inconsistency effect was studied on the same word which is either rendered consistent or inconsistent through its preceding pre-target, taking out any possible interference from lexical characteristics on the main effect of interest. Inconsistent pre-targets were created by choosing a key word in the text and replacing it with a plausible alternative (e.g. soya was replaced with corn). All chosen target words were high-frequency nouns or verbs $(\mathrm{M}=4.7$ (SD = 0.6) Zipf frequency in the SUBTLEX-UK Heuven, Mandera, Keuleers, $\&$ Brysbaert, 2014) of on average $6(\mathrm{SD}=1.6)$ letters length. All pre-targets were placed at equal distance before the targets ( 20 words and 2 sentences). Pre-targets were also matched in lengths across conditions ( $<2$ letters difference) and frequency $(\mathrm{M}=$ $4.7(\mathrm{SD}=0.6)$ Zipf frequency for consistent pre-targets and $\mathrm{M}=4.7(\mathrm{SD}=0.7)$ for inconsistent pre-targets in the SUBTLEX-UK), which also means that pre-target and target were matched on length and frequency within inconsistent stories. To also avoid interference through clause or sentence wrap-up, target words were followed by minimally three words.

Word processing difficulty was manipulated on the text level by replacing five words in each context with a lower-frequency and longer alternative (see Table 3), thereby creating a difficult and an easy version of each text. Words were replaced throughout the texts to create a clear general difference in word processing difficulty 
between texts read in the easy and difficult condition. Word frequency was checked in two corpora, the SUBTLEX-UK which reflects the English language used in films and series and the British National Corpus that reflects English language usage in written texts (2007); thereby tapping two of the main sources of our participants' English language input.

[Table 3: near here]

Stories were split into four lists following a Latin square design where each participant read all 48 stories once, 24 in the consistent and 24 in the inconsistent condition. Inconsistency was crossed with word processing difficulty by having participants read 12 consistent texts with easy words and 12 with difficult words, and vice versa for the inconsistent condition.

To encourage reading for meaning, the participants were told that after having read four texts, they would be asked to recall each story orally, prompted by a keyword. Participants were free to recall texts in either English or German, with all participants choosing to recall the texts in their first language, German. Comprehension was scored for the number of idea units recalled from each story by two trained raters. An interrater reliability check on $14 \%$ of the data that had been independently scored by both raters confirmed their good reliability (inter-class correlation coefficient $2 \mathrm{k}=0.72$ ). On average, participants recalled more than half the idea units $(\mathrm{M}=61 \%, \mathrm{SD}=3 \%)$, confirming that they had read for meaning.

The texts were presented via Experiment Builder software (SR Research, 2009) and eye movements were recorded using an Eyelink 1000 eye tracker at a sampling rate of $1000 \mathrm{~Hz}$. Texts were formatted in black, Courier New font, size 18, with double spacing, and on a white background. Participants read the texts silently from a Dell Alienware AW2518HF monitor, set at a refresh rate of $60 \mathrm{~Hz}$ with $1024 \times 768$ 
resolution, at a viewing distance of $60 \mathrm{~cm}$. Although our participants read with both eyes, only the right eye was monitored, unless problems (e.g. reflections on glasses) made it necessary to switch to the left eye to gain better data quality. A chin and forehead rest was used to minimize head movements. The camera was calibrated on a five-point grid and each trial started with drift corrections to make sure calibration was sufficiently precise $\left(<0.5^{\circ}\right.$ of accuracy). Calibration was repeated after each recall or break and as necessary.

\section{Procedure}

Participants were tested in a university laboratory in a 1.5 hour long individual session. After a short instruction phase where participants also read one trial text, they started with the reading task. Participants read at their own pace and moved on after reading a text by pressing a button on a gamepad. During the two breaks that participants took, each time after having read 16 texts, they completed the offline language measures and the language background questionnaire. All procedures and measures were approved by the departmental ethics committee.

\section{Eye movement pre-processing}

The eye movement data was cleaned and analyzed using popEye (Schroeder, 2019). During pre-processing, gaze drift was corrected automatically and fixations shorter than $80 \mathrm{~ms}$ were first merged within 1 letter distance and then, fixations shorter than $40 \mathrm{~ms}$ were merged within 2 letters distance. Eye movements on inconsistency targets (e.g. soya) and word processing difficulty manipulated words (e.g. dangerous or alarming) were distilled into early measures (gaze duration and first-pass text reading, thought to tap word identification) and late measures (such as go-past duration, rereading time or regression probabilities, thought to reflect text-integration processes). 


\section{Results}

The data were analyzed in $\mathrm{R}$ ( $\mathrm{R}$ Core Team, 2016) using linear and binomial mixed effect models from the lme4 package version 1.1-21 (Bates, Mächler, Bolker, \& Walker, 2015). Before running the models, the data were cleaned as follows. First, trials were deleted if the target word had been skipped in the first run, which was the case for $14 \%$ of all trials. Then, extremely long and short reading times (gaze durations below 50ms or above $800 \mathrm{~ms}$; go-past durations, rereading and total times above $4000 \mathrm{~ms}$; whole text reading times above 4.7 minutes for first-pass and above 8.3 minutes for second-pass reading) were deleted, followed by model-based deletions based on a cut-off of 2.5 standard deviations from the person and item means for each reading time measure. For each measure, this removed on average $1.8 \%(\mathrm{SD}=2.1 \%)$ of the data. Reading times were log-transformed. Then, the models were run with the fixed effects inconsistency (consistent vs. inconsistent) and word processing difficulty (easy vs. difficult words). Crossed random intercepts and slopes by inconsistency and word processing difficulty were included for participants and items. Item random effects were estimated by stimuli texts (for models predicting reading on inconsistency targets) or by word processing difficulty targets (for models predicting reading on the words manipulated for word processing difficulty). This random structure was only reduced when high intercorrelation and singularity of random effects caused convergence problems (Barr, Levy, Scheepers, \& Tily, 2013). Effect coding and Type II model comparisons were used to determine the significance of the fixed effects using the Anova function of the car package (Fox, Friendly, \& Weisberg, 2013). Post-hoc tests were run using cell means 
models and single degree of freedom contrasts implemented in the glht function of the multcomp package (Hothorn, Bretz, \& Westfall, 2008) ${ }^{1}$.

\section{Inconsistency main effects}

We begin by reporting L2 learners' reading of consistent and inconsistent target words. The observed means are summarized in Table 4, and the results of our mixed effect models are summarized in Table 5. The models showed that inconsistent targets were read for longer than consistent targets, both in early and late reading measures (as evident in longer gaze and go-past durations and rereading as well as total times). Inconsistent targets also received more rereading and direct regressions in, as summarized in Figure 1.

[Figure 1: near here]

[Table 4: near here]

[Table 5: near here]

\section{Word processing difficulty main effects}

Word processing difficulty affected L2 learners' reading of the manipulated words as well as on the whole texts. The observed means are summarized in Table 6 and the results of our mixed effect models are summarized in Table 7 . The models showed that as intended, difficult words were read for longer than easy words, both in early and late reading measures (as evident in longer gaze and go-past durations and longer rereading as well as total times). They also received more rereading and direct regressions in, as

\footnotetext{
${ }^{1}$ We reran all analyses on a sub-sample of 54 participants that excluded intermediate proficiency learners (who performed at level B1 and lower on the LexTALE) to ensure that participants below the expected level of English proficiency of the target population (Kultusministerkonferenz, 2012) did not unduly affect the results. As all results remained qualitatively the same, we only report them for the full sample.
} 
summarized in
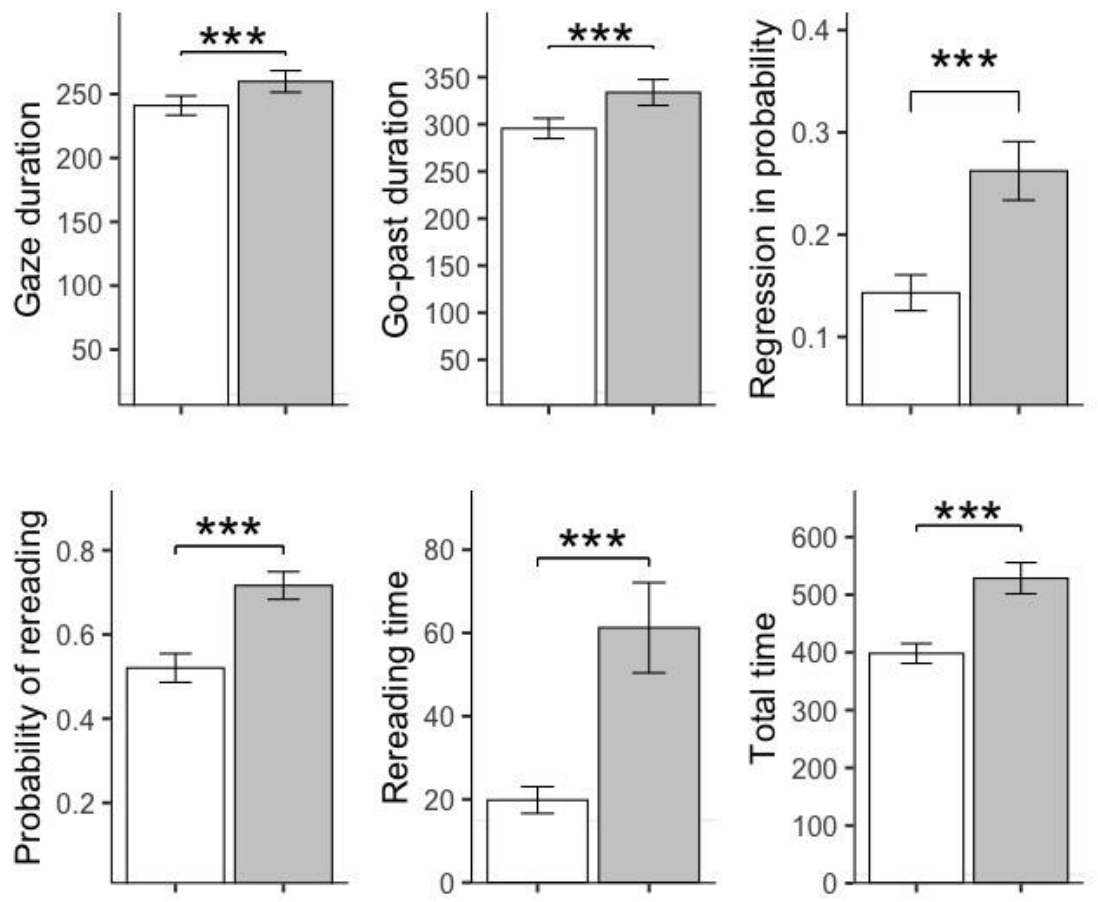

Figure 2. The processing effort induced by more difficult words also lead to longer reading of the whole text, both in first- and second-pass reading (see Tables 6 and 7).

[Figure 2: near here]

[Table 6: near here]

[Table 7: near here]

\section{Effect of word processing difficulty on inconsistency reading}

We now turn to reporting the relationship between word processing difficulty and L2 learners' reading of inconsistent or consistent targets. As predicted, the two variables interactively influenced rereading behavior, as evident in the predicted statistical interaction effects on rereading time and probability, as well as go-past duration (see Table 5). Post-hoc comparisons showed that L2 learners adjusted their go-past durations and reading less to inconsistencies when reading in the difficult as opposed to the easy condition, as visible in significant interactions between inconsistency and word 
processing difficulty in go-past duration $(z=2.0, p<.05)$, rereading time $(z=2.0, p<$ $.05)$, and rereading probability $(z=2.5, p<.05)$. The interaction was driven by $\mathrm{L} 2$ learners reading inconsistencies longer than consistent information when the word processing difficulty was low $(z=2.7, p<.001$ for go-past duration, $z=6.7, p<.0001$ for rereading time and $z=6.8, p<.0001$ for rereading probability), while not increasing their rereading equally strongly when reading inconsistencies in texts with a word processing difficulty $(z=2.7, p<.01$ for go-past duration, $z=4.5, p<.0001$ for rereading time and $z=3.9, p<.0001$ for rereading probability). In other words, the significant interactions between word processing difficulty and inconsistency were driven by a still visible but reduced inconsistency effect on difficult texts. These key interactions are shown in Figure 3.

Note, however, that against our predictions, the two factors did not interactively influence regression in probability, although there was a clear main effect of inconsistency on this measure.

[Figure 3: near here]

\section{Discussion}

We investigated interactions between lower-level word processing and higher-level coherence-building when reading in an L2. Both were manipulated experimentally and on the text level: to create two levels of lower-level word processing difficulty, we inserted either longer and low-frequency or shorter and high-frequency words in our texts, thereby creating within-person variations of word processing difficulty. To tap higher-level processing, we manipulated our target words' consistency with preceding information, thereby tapping readers coherence-building. The experimental manipulation of both inconsistency and word processing difficulty is an important design feature of our study as it allows us to isolate the effect of word processing 
difficulty experimentally instead of inferring it from correlations with individual differences (Castles et al., 2018; Hopp, 2016b; McDonald, 2006). We expected that both word processing difficulty and inconsistency would be evident in longer processing times in the eye movement record. If the two interacted, we expected this to show in rereading behavior, where we predicted a reduced inconsistency effect in the difficult condition, both in terms of rereading times and regression probabilities. If an interaction was found, this would support the influence of lower-level word processing on higher-level coherence-building. If, however, inconsistency rereading was not or only partially affected by word processing difficulty, this would indicate a limited interaction between the two processing levels. Our results expose the expected interaction between lower- and higher-level processing, thus illuminating both the basis and the limits of skillful reading. The following discusses the results in more detail.

We found a clear inconsistency effect in rereading, showing that our design was sensitive to higher-level coherence building. As predicted, reading in the inconsistent as opposed to the consistent condition was associated with longer gaze and go-past durations and rereading times as well as increased regressions on inconsistent compared to consistent target words. These reading patterns resonate with previous studies that reported longer go-past durations and rereading for inconsistent and anomalous words and structures compared to controls, both when reading in an L1 (Connor et al., 2015; Eilers et al., 2018; Hessel et al., 2020; Joseph et al., 2008; Kim et al., 2018; Kinnunen \& Vauras, 1995; Rayner et al., 2004; van der Schoot et al., 2012; Vorstius et al., 2013; Weiss et al., 2017; Zabrucky \& Ratner, 1989) and an L2 (Lim \& Christianson, 2014). Thus, our data further support the idea that inconsistency processing requires additional re-analysis, and that this process is particularly visible in both longer and more frequent rereading of inconsistent information. To our knowledge, ours is the first study to have 
looked at this in the context of L 2 readers processing of expository text passages, thereby expanding the literature on the inconsistency paradigm to reading informational texts in an L2, which is a ubiquitous reading context in higher education and the business world. Future research could see if similar online markers of coherencebuilding in L2 expository text reading could also be observed using longer, more naturalistic texts.

We also found a clear effect of word processing difficulty on reading, showing that our manipulation successfully altered the ease of lower-level word processing. As predicted, higher compared to lower word processing difficulty was associated with longer gaze durations, go-past and rereading times on the difficulty manipulated words as well as with longer first-pass reading on the whole text. These reading patterns are in line with the previously reported slower reading times in response to increased word length and lower frequency - the two operationalizations of word processing difficulty in our study (Gagl et al., 2015; Inhoff \& Rayner, 1986; Joseph et al., 2009, 2013; Juhasz \& Rayner, 2006; Tiffin-Richards \& Schroeder, 2015). Furthermore, the observed reading patterns are akin to reported associations between L2 readers' individual differences in word processing difficulty, for example due to varying vocabulary size or L2 input (Hopp, 2016b; Lim \& Christianson, 2014; van den Bosch et al., 2018; Whitford \& Titone, 2012). That is, the variations in reading processing associated with our within-subject manipulation of word processing difficulty mirror individual differences. In line with McDonald (2006), we thus suggest that our findings may point towards word processing difficulty as the driving force behind the individual differences in L2 reading observed in other studies, a suggestion that remains to be tested by a direct comparison of individual and experimentally induced differences in the same study. 
The core theoretical interest of our study rests on whether there is a statistical interaction between lower-level (tapped by word processing difficulty) and higher-level processing (visible in inconsistency processing). If a statistical interaction was found between word processing and inconsistency reading, this would be evidence in favor of lower-level processes directly affecting higher-level processing. This indeed was the result. Word processing difficulty interacted with inconsistency in go-past duration, rereading time and rereading probability. In the easy condition, readers spent less time rereading consistent than inconsistent targets, leading to the larger inconsistency effect that is characteristic for skillful reading. When reading in the difficult condition, however, the inconsistency effect was reduced compared to the easy condition. That is to say, readers spent less additional time re-analyzing inconsistent information when reading a text full of difficult words. Our readers' reduced inconsistency effect seems to indicate that they had reached their maximum processing effort: already when reading texts full of easy words, the L2 readers had a 75\% probability of rereading inconsistent information. This amount of rereading leaves little spare capacity for increased rereading when further effort is needed, as was the case in the difficult condition. Arguably, the high word processing load thus led L2 readers to be at ceiling, which limited the amount of effort they could invest in coherence-building.

The observed interaction between lower- and higher-level processing exposes the often-cited bottleneck of reading processing: when the limits of the language system's processing capacities are reached, an increased lower-level processing load will limit higher-level coherence-building. Or, put differently, if lower-level processing takes up all or most processing capacity, higher-level processes, such as coherencebuilding, are reduced (Perfetti \& Stafura, 2014). To again draw a link between individual differences and experimentally induced word processing difficulties 
(McDonald, 2006), our results can be seen as an experimental simulation of how, due to less developed word knowledge, younger and less skilled readers' higher-level processing is limited by more effortful lower-level word processing (Connor et al., 2015; Eilers et al., 2018; Hessel et al., 2020; Reichle et al., 2013). Our study also links to and extends previous experimental work on word processing difficulty in L2 sentence comprehension (Hopp, 2016b; McDonald, 2006) by extending it to text-level coherence-building, an aspect of reading where interactions between lower- and higherlevel processing are still largely unexplored (van den Broek \& Helder, 2017). Note, however, that in order to design a high-powered study with a sufficient number of observations, our stimuli ended up being short and dense compared to everyday reading materials. Future studies could investigate in how far our observed interactions between lower-level and higher-level processing replicate in longer and more naturalistic texts.

While our results demonstrate interactions between lower-level word processing and higher-level coherence-building, they also indicate possible boundaries to this effect: in contrast to go-past durations, rereading time and probability, our experimentally-induced differences in word processing difficulty did not affect regressions in, neither in interaction with inconsistency nor as a main effect. This is unexpected given that regressions into inconsistent information has previously been found to vary with individual differences in word knowledge (Eilers et al., 2018; Hessel et al., 2020). While our study differs from previous work in terms of observed readers, text types and study design (experimental vs. individual differences), the fact remains that word processing difficulty influenced all but one area of inconsistency rereading, namely, regressions in. Our experimental manipulation thus yielded no support that lower-level processing interacts with a reader's ability to target the source of higherlevel difficulties; an ability which has previously been suggested to be a trademark of 
skillful higher-level processing (Murray \& Kennedy, 1988). A stronger interpretation, which is yet to be demonstrated, is that targeted rereading of inconsistent information may be - more so than general rereading - moderated by other factors than word processing difficulty, such as working memory or standards of coherence. Working memory - understood here as both storage space and executive control mechanisms (Baddeley, 2003) - is likely necessary for readers to monitor reading and shift their attention to the exact location of coherence breaks when necessary. Since we did not manipulate nor measure our readers' working memory capacities, they remained the same across conditions and may well explain high regression in probabilities regardless of word processing difficulty. A similar argument can be made for individual differences in standards of coherence, which may support targeted processing of coherence breaks (van den Broek \& Helder, 2017). A possible refinement of our conclusions on interactions between lower- and higher-level processing could thus be that certain aspects of coherence-building, such as targeted regressions, may be more strongly affected by a reader's cognitive architecture (Perfetti \& Stafura, 2014) or topdown regulation (van den Broek \& Helder, 2017) than by word processing. This hypothesis could be tested by measuring or manipulating working memory and standards of coherence alongside word processing difficulty in order to observe their mutual interactions in reading processing.

There are three considerations in interpreting our results. First, due to the unexpectedly low reliability of the chosen vocabulary measure LexTALE (Lemhöfer \& Broersma, 2012), we did not account for vocabulary differences in our analyses, meaning that we cannot report on individual differences in reading processing. Second, word processing difficulty was manipulated through a combination of length and frequency effects. While both of them served the intended effect of making word 
processing more effortful, their respective contribution to the observed interactions with higher-level processing could be teased apart more clearly in future studies.

A third qualification concerns the ceiling effect in rereading, which, as much as it chimes with theoretical considerations, may be specific to the exact reading situation and population in our study. Both being adult university students (with arguably larger working memory capacities than developing readers) and being asked to recall each text after reading could have increased rereading in general, and thus contributed to the observed ceiling effect. In how far the same effects will show in other reading contexts could be tested in future studies with younger readers or less demanding comprehension checks.

\section{Conclusion}

The present study adds to previous research on interactions between lower- and higherlevel reading processing in the following specific ways: first, our results are the first to provide experimental evidence for a bottleneck in higher-level coherence-building in the face of increased lower-level processing load, beyond correlations with offline measures. In addition, we studied this interaction in the context of L2 expository text reading, an under researched yet ubiquitous reading context in higher education and businesses worldwide.

In broader theoretical terms, our study joins others' (Eilers et al., 2018; Hessel et al., 2020; Perfetti \& Stafura, 2014; Yang, Perfetti, \& Schmalhofer, 2007) in exposing interactions between local, lower-level word processing and higher-level reading comprehension, thus displaying a chain-reaction that starts with a higher load in bottomup processes at the word-level and ends in reduced processing at the text-level. The theoretical question of interest is when and why lower- and higher-level processes mutually interact, and how these interactions may vary or remain stable across readers 
or tasks. Our findings on a bottleneck of reduced coherence-building in the face of high word processing difficulty exposes one key feature of moment-to-moment comprehension: when a reader is well up to the reading task, all components of reading can run smoothly and largely independently, but when a limit is reached, sacrifices need to be made - and that may well mean for higher-level comprehension to go out of the window.

For teaching, our findings support the idea that building a strong basis of word knowledge is a good support for reading comprehension - both for individual words and higher-level connections (Willingham, 2017). Further work will be needed to determine how interventions targeting reading tasks and strategy training - which can be used to alter a readers' standards of coherence - could additionally support moment-to-moment reading processing, beyond the effects of word processing (Gold, 2018).

Our hypothesis is that, aside from other between-reader differences, a critical causal factor to either support or jeopardize higher-level comprehension is the ease of word processing (Perfetti \& Stafura, 2014), and that word processing has consequences for coherence-building and higher-level comprehension. It is possible that, besides lower-level word processing, targeted regressions into to-be-analyzed information in particular are further influenced by a reader's working memory and executive control, or their standards of coherence (van den Broek \& Helder, 2017).

The ultimate question is how all of a reader's knowledge, capacities and deliberate intentions come together to create skillful and adaptive moment-to-moment comprehension. To answer it, we need to better understand which elements of higherlevel comprehension are causally influenced by word processing, working memory, or reading intentions, and how these mechanisms mutually interact to create skillful reading. 


\section{Acknowledgements}

We want to thank Barbara Götze and Lisa Schorn for their great contribution to data collection.

\section{Declaration of Interest Statement}

The author(s) declared that there were no conflicts of interest with respect to the authorship or the publication of this article. 


\section{References}

Albrecht, J. E., \& O’Brien, E. J. (1993). Updating a mental model: Maintaining both local and global coherence. Journal of Experimental Psychology: Learning, Memory, and Cognition, 19(5), 1061-1070. https://doi.org/10.1037/0278-7393.19.5.1061

Baddeley, A. (2003). Working memory: looking back and looking forward. Nature Reviews Neuroscience, 4(10), 829-839. https://doi.org/10.1038/nrn1201

Barr, D. J., Levy, R., Scheepers, C., \& Tily, H. J. (2013). Random effects structure for confirmatory hypothesis testing : keep it maximal. Journal of Memory and Language, 68(3), 255-278. https://doi.org/10.1016/j.jml.2012.11.001

Block, E. L. (1992). See how they read: comprehension monitoring of L1 and L2 readers. TESOL Quarterly, 26(2), 319-343. https://doi.org/10.2307/3587008

Braet, W., Noppe, N., Wagemans, J., \& Op de Beeck, H. (2011). Increased stroop interference with better second-language reading skill. Quarterly Journal of Experimental Psychology, 64(3), 596-607. https://doi.org/10.1080/17470218.2010.513735

Castles, A., Rastle, K., \& Nation, K. (2018). Ending the reading wars: reading acquisition from novice to expert. Psychological Science in the Public Interest, 19(1), 5-51. https://doi.org/10.1177/1529100618772271

Connor, C. M., Radach, R., Vorstius, C., Day, S. L., Mclean, L., Morrison, F. J., \& Mcdonald, C. (2015). Individual differences in fifth graders' literacy and academic language predict comprehension monitoring development: an eye-movement study. Scientific Studies of Reading, 19(2), 114-134. https://doi.org/10.1080/10888438.2014.943905

Cop, U., Drieghe, D., \& Duyck, W. (2015). Eye movement patterns in natural reading: A comparison of monolingual and bilingual reading of a novel. PLOS ONE. https://doi.org/10.1371/journal.pone.0134008

Eilers, S., Tiffin-Richards, S. P., \& Schroeder, S. (2018). Individual differences in children's pronoun processing during reading: detection of incongruence is associated with higher reading fluency and more regressions. Journal of Experimental Child Psychology, 173, 250-267. https://doi.org/S0022096517304770

Fox, J., Friendly, M., \& Weisberg, S. (2013). Hypothesis tests for multivariate linear models using the car package. The R Journal, 5(1), 39-52.

Gagl, B., Hawelka, S., \& Wimmer, H. (2015). On sources of the word length effect in young readers. Scientific Studies of Reading, 19(4), 289-306. https://doi.org/10.1080/10888438.2015.1026969 
Gold, A. (2018). Lesen kann man lernen. Göttingen: Vandenhoeck \& Ruprecht.

Hessel, A., Nation, K., \& Murphy, V. A. (2020). English as an additional language learners' comprehension monitoring during reading: an eye-tracking study. Scientific Studies of Reading.

Heuven, W. J. B. Van, Mandera, P., Keuleers, E., \& Brysbaert, M. (2014). SUBTLEX-UK: A new and improved word frequency database for British English. The Quarterly Journal of Experimental Psychology, 67(6), 1176-1190.

Hopp, H. (2016a). Cross-linguistic lexical and syntactic co-activation in L2 sentence processing. Linguistic Approaches to Bilingualism, 2(October), 96-130. https://doi.org/10.1075/lab.14027.hop

Hopp, H. (2016b). The timing of lexical and syntactic processes in second language sentence comprehension. Applied Psycholinguistics, 37(5), 1253-1280. https://doi.org/10.1017/S0142716415000569

Horiba, Y. (2012). Word knowledge and its relation to text comprehension: a comparative study of Chinese- and Korean-speaking L2 learners and L1 speakers of Japanese. Modern Language Journal, 96(1), 108-121. https://doi.org/10.1111/j.1540-4781.2012.01280.x

Hosoda, M. (2016). The interplay of text cohesion and L2 reading proficiency in different levels of text comprehension among EFL readers. ARELE: Annual Review of English Language Education in Japan, 27, 201-216. https://doi.org/10.20581/arele.27.0_201

Hothorn, T., Bretz, F., \& Westfall, P. (2008). Simultaneous inference in general parametric models. Biometrical Journal, 50(3), 346-363.

Inhoff, A. W., \& Rayner, K. (1986). Parafoveal word processing during eye fixations in reading: effects of word frequency. Perception \& Psychophysics, 40(6), 431-439. https://doi.org/10.3758/BF03208203

Jensen, A. R., \& Rohwer, W. D. J. (1966). The Stroop color-word test: a review. Acta Psychologica, 25, 36-93.

Joseph, H. S. S. L., Liversedge, S. P., Blythe, H. I., White, S. J., Gathercole, S. E., \& Rayner, K. (2008). Children's and adults' processing of anomaly and implausibility during reading: evidence from eye movements. The Quarterly Journal of Experimental Psychology, 61(5), 708-723. https://doi.org/10.1080/17470210701400657

Joseph, H. S. S. L., Liversedge, S. P., Blythe, H. I., White, S. J., \& Rayner, K. (2009). Word length and landing position effects during reading in children and adults. Vision Research, 49(16), 2078-2086. https://doi.org/10.1016/j.visres.2009.05.015 
Joseph, H. S. S. L., Nation, K., \& Liversedge, S. (2013). Using eye movements to investigate word frequency effects in children's sentence reading. School Psychology Review, 42(2), 207-222.

Juhasz, B. J., \& Rayner, K. (2006). The role of age of acquisition and word frequency in reading: evidence from eye fixation durations. Visual Cognition, 13(7-8), 846-863. https://doi.org/10.1080/13506280544000075

Kaakinen, J. K., \& Hyönä, J. (2005). Perspective effects on expository text comprehension: evidence from think-aloud protocols, eyetracking, and recall. Discourse Processes, 40(3), 239-257. https://doi.org/10.1207/s15326950dp4003

Kaakinen, J. K., Hyönä, J., \& Keenan, J. M. (2003). How prior knowledge, WMC, and relevance of information affect eye fixations in expository text. Journal of Experimental Psychology. Learning, Memory, and Cognition, 29(3), 447-457. https://doi.org/10.1037/0278-7393.29.3.447

Kim, Y. S., Vorstius, C., \& Radach, R. (2018). Does online comprehension monitoring make a unique contribution to reading comprehension in beginning readers? Evidence from eye movements. Scientific Studies of Reading, 22(5), 367-383. https://doi.org/10.1080/10888438.2018.1457680

Kinnunen, R., \& Vauras, M. (1995). Comprehension monitoring and the level of comprehension in high- and low-achieving primary school children's reading. Learning and Instruction, 5(2), 143-165. https://doi.org/10.1016/0959-4752(95)00009-R

Kultusministerkonferenz. (2012). Bildungsstandards für die fortgeführte Fremdsprache (Englisch/Französisch) für die Allgemeine Hochschulreife. Beschluss der Kultusministerkonferenz von 18. 10. 2012. Berlin.

Lemhöfer, K., \& Broersma, M. (2012). Introducing LexTALE: a quick and valid lexical test for advanced learners of English. Behavior Research Methods, 44, 325-343. https://doi.org/10.3758/s13428-011-0146-0

Libben, M. R., \& Titone, D. A. (2009). Bilingual lexical access in context: evidence from eye movements during reading. Journal of Experimental Psychology: Learning Memory and Cognition, 35(2), 381-390. https://doi.org/10.1037/a0014875

Lim, J. H., \& Christianson, K. (2014). Second language sensitivity to agreement errors: evidence from eye movements during comprehension and translation. Applied Psycholinguistics, 36(6), 1283-1315. https://doi.org/10.1017/S0142716414000290

McDonald, J. L. (2006). Beyond the critical period: Processing-based explanations for poor grammaticality judgment performance by late second language learners. Journal of 
Memory and Language, 55(3), 381-401. https://doi.org/10.1016/j.jml.2006.06.006

Murray, W. S., \& Kennedy, A. (1988). Spatial coding in the processing of anaphor by good and poor readers: evidence from eye movement analyses. The Quarterly Journal of Experimental Psychology, 40(4), 693-718. https://doi.org/10.1080/14640748808402294

O’Brien, E. J., \& Albrecht, J. E. (1992). Comprehension Strategies in the Development of a Mental Model. Journal of Experimental Psychology: Learning, Memory, and Cognition, 18(4), 777-784. https://doi.org/10.1037/0278-7393.18.4.777

O’Brien, E. J., Cook, A. E., \& Guéraud, S. (2010). Accessibility of Outdated Information. Journal of Experimental Psychology: Learning Memory and Cognition, 36(4), 979-991. https://doi.org/10.1037/a0019763

Pérez, A. M., \& Bajo, M. T. (2019). The nature of first and second language processing: the role of cognitive control and L2 proficiency during text-level comprehension. Bilingualism: Language and Cognition, 22(5), 930-948. https://doi.org/10.1017/S1366728918000846

Perfetti, C. (1985). Reading ability. New York: Oxford University Press.

Perfetti, C., \& Stafura, J. (2014). Word knowledge in a theory of reading comprehension. Scientific Studies of Reading, 18(1), 22-37. https://doi.org/10.1080/10888438.2013.827687

Perfetti, C., Yang, C.-L., \& Schmalhofer, F. (2008). Comprehension skill and word-to-text integration processes. Applied Cognitive Psychology, 22, 303-318. https://doi.org/10.1002/acp

R Core Team. (2016). R: a language and environment for statistical computing. Retrieved from http://www.r-project.org/

Raudszus, H., Segers, E., \& Verhoeven, L. (2019). Situation model building ability uniquely predicts first and second language reading comprehension. Journal of Neurolinguistics, 50(October 2018), 106-119. https://doi.org/10.1016/j.jneuroling.2018.11.003

Rayner, K., Warren, T., Juhasz, B. J., \& Liversedge, S. P. (2004). The effect of plausibility on eye movements in reading. Journal of Experimental Psychology: Learning, Memory, and Cognition, 30(6), 1290-1301. https://doi.org/10.1037/0278-7393.30.6.1290

Reichle, E. D., Liversedge, S. P., Drieghe, D., Blythe, H. I., Joseph, H. S. S. L., White, S. J., \& Rayner, K. (2013). Using E-Z Reader to examine the concurrent development of eyemovement control and reading skill. Developmental Review, 33(2), 110-149. https://doi.org/10.1016/j.dr.2013.03.001

Schotter, E. R., Tran, R., \& Rayner, K. (2014). Don't believe what you read (only once): 
comprehension is supported by regressions during reading. Psychological Science, 25(6), 1218-1226. https://doi.org/10.1177/0956797614531148

Schroeder, S. (2019). popEye - An R package to analyse eye movement data from reading experiments.

SR Research. (2009). Experiment Builder.

Stafura, J. Z., \& Perfetti, C. A. (2014). Word-to-text integration: message level and lexical level influences in ERPs. Neuropsychologia, 64, 41-53.

https://doi.org/10.1016/j.neuropsychologia.2014.09.012

The British National Corpus. (2007). Retrieved from http://www.natcorp.ox.ac.uk/

Tiffin-Richards, S. P., \& Schroeder, S. (2015). Word length and frequency effects on children's eye movements during silent reading. Vision Research, 113, 33-43. https://doi.org/10.1016/j.visres.2015.05.008

Torgesen, J. K., Rashotte, C. A., \& Wagner, R. K. (2012). TOWRE 2: test of word reading efficiency. Austin, Texas : Pro-Ed.

van den Bosch, L. J., Segers, E., \& Verhoeven, L. (2018). Online processing of causal relations in beginning first and second language readers. Learning and Individual Differences, 61, 59-67. https://doi.org/10.1016/j.lindif.2017.11.007

van den Broek, P., \& Helder, A. (2017). Cognitive processes in discourse comprehension: passive processes, reader-initiated processes, and evolving mental representations. Discourse Processes, 54(5-6), 360-372. https://doi.org/10.1080/0163853X.2017.1306677

van der Schoot, M., Reijntjes, A., \& van Lieshout, E. C. D. M. (2012). How do children deal with inconsistencies in text? An eye fixation and self-paced reading study in good and poor reading comprehenders. Reading and Writing, 25(7), 1665-1690. https://doi.org/10.1007/s11145-011-9337-4

Vorstius, C., Radach, R., Mayer, M. B., \& Lonigan, C. J. (2013). Monitoring local comprehension monitoring in sentence reading. School Psychology Review, 42(2), 191206.

Weiss, A. F., Kretzschmar, F., Schlesewsky, M., Bornkessel-Schlesewsky, I., \& Staub, A. (2018). Comprehension demands modulate re-reading, but not first pass reading behavior. The Quarterly Journal of Experimental Psychology, 71(1), 198-210. https://doi.org/10.1080/17470218.2017.1307862

Whitford, V., \& Titone, D. (2012). Second-language experience modulates first- and secondlanguage word frequency effects: evidence from eye movement measures of natural 
paragraph reading. Psychonomic Bulletin and Review, 19(1), 73-80.

https://doi.org/10.3758/s13423-011-0179-5

Willingham, D. (2017). The reading mind: a cognitive approach to understanding how the mind reads. Oxford: Wiley.

Yang, C. L., Perfetti, C. A., \& Schmalhofer, F. (2007). Event-related potential indicators of text integration across sentence boundaries. Journal of Experimental Psychology: Learning Memory and Cognition, 33(1), 55-89. https://doi.org/10.1037/0278-7393.33.1.55

Yeari, M., Oudega, M., \& van den Broek, P. (2017). The effect of highlighting on processing and memory of central and peripheral text information: evidence from eye movements. Journal of Research in Reading, 40(4), 365-383. https://doi.org/10.1111/1467-9817.12072

Yeari, M., van den Broek, P., \& Oudega, M. (2015). Processing and memory of central versus peripheral information as a function of reading goals: evidence from eye-movements. Reading and Writing, 28(8), 1071-1097. https://doi.org/10.1007/s11145-015-9561-4

Zabrucky, K., \& Ratner, H. H. (1989). Effects of reading ability on children's comprehension evaluation and regulation. Journal of Reading Behavior, 21(1), 69-83.

Zwaan, R. A., \& Madden, C. J. (2004). Updating Situation Models. Journal of Experimental Psychology: Learning Memory and Cognition, 30(1), 283-288.

https://doi.org/10.1037/0278-7393.30.1.283 


\section{Appendices}

\section{Appendix A: Language Background Questionnaire}

\section{German version used in study:}

„Da du in unserer Studie englisch Texte liest, werde ich auch kurz ein paar Fragen zu deinem Sprachenlernen stellen.“

\section{A Language Learning History}

1. Seit wann hast Du Deutsch gelernt?

Hast Du noch eine andere Sprache daheim gesprochen?

2. Welche Sprachen sprichst Du noch außer Deutsch, und wie hast Du sie gelernt?

\begin{tabular}{|l|l|}
\hline Sprache & $\begin{array}{l}\text { Wo gelernt (z.B. Schule, Familie, Sprachkurs, } \\
\text { Auslandsaufenthalt) }\end{array}$ \\
\hline & \\
\hline & \\
\hline & \\
\hline & \\
\hline
\end{tabular}

"Jetzt stelle ich dir ein paar Fragen ganz speziell zum Englischlernen."

3. Wie alt warst Du, als Du angefangen hast Englisch zu lernen?

4. Was war Deine Englischnote im Abitur?

○ Keine Ahnung.

5. Hast Du einen Auslandsaufenthalt im englisch-sprachigen Ausland gemacht? ja 0 nein 0

Wenn ja, wie lang hat dieser gedauert?

6. Wie würdest Du deine heutigen Englischkenntnisse einschätzen?

Dazugehörige Antwortskala:

\begin{tabular}{|l|l|l|l|l|}
$\begin{array}{l}\text { Ich kann gar } \\
\text { kein Englisch. }\end{array}$ & & & & $\begin{array}{l}\text { Wie ein } \\
\text { Muttersprachler }\end{array}$ \\
\hline 1 & 2 & 3 & 4 & 5 \\
\hline
\end{tabular}

Sprachverstehen:

Sprechen/ Schreiben: 


\section{B. Current English Use}

„Abschließend möchte ich gerne wissen, wie oft Du Englisch in Deiner Freizeit nutzt.“

7. Hast Du Freunde oder Bekannte, mit denen Du Englisch redest?

$$
\text { Ja } 0 \text { nein } 0
$$

Wenn ja: Wie häufig?

\begin{tabular}{|l|l|l|l|l|}
\hline $\begin{array}{l}\text { Unregelmäßig, } \\
\text { z.B. im Urlaub }\end{array}$ & $\begin{array}{l}\text { Seltener als } \\
\text { 1x pro } \\
\text { Monat }\end{array}$ & $\begin{array}{l}\text { Seltener als } \\
\text { 1x pro } \\
\text { Woche }\end{array}$ & $\begin{array}{l}1-2 \mathrm{x} \text { pro } \\
\text { Woche }\end{array}$ & $\begin{array}{l}\text { 3x oder } \\
\text { mehr pro } \\
\text { Woche }\end{array}$ \\
\hline & & & & \\
\hline
\end{tabular}

8. Denke an die letzten vier Wochen. Wie oft hast Du Englisch für die folgenden Aktivitäten genutzt, relativ zu Deutsch?

Antwortskala für "Wie oft (generell)?" Frage:

\begin{tabular}{|l|l|l|}
\hline Nie & Manchmal & Häufig \\
\hline 1 & 2 & 3 \\
\hline
\end{tabular}

Antwortskala für "Wie of in Englisch oder Deutsch?" Frage:

\begin{tabular}{|l|l|l|l|l|}
\hline $\begin{array}{l}\text { Immer } \\
\text { auf } \\
\text { Deutsch }\end{array}$ & $\begin{array}{l}\text { Häufiger auf } \\
\text { Deutsch als } \\
\text { auf Englisch }\end{array}$ & $\begin{array}{l}\text { Ungefähr gleich } \\
\text { häufig auf } \\
\text { Deutsch oder } \\
\text { Englisch }\end{array}$ & $\begin{array}{l}\text { Häufiger auf } \\
\text { Englisch als } \\
\text { auf Deutsch }\end{array}$ & $\begin{array}{l}\text { Immer auf } \\
\text { Englisch }\end{array}$ \\
\hline 1 & 2 & 3 & 4 & 5 \\
\hline
\end{tabular}

Keine

Ahnung.

\begin{tabular}{|l|l|l|}
\hline & Wie oft? & $\begin{array}{l}\text { Wie oft in Englisch oder } \\
\text { Deutsch? }\end{array}$ \\
\hline $\begin{array}{l}\text { 1. Youtube Videos oder Filme/ } \\
\text { Serien schauen }\end{array}$ & & \\
\hline 2. Bücher/ Paper lesen & & \\
\hline 3. Podcasts/ Radio hören & & \\
\hline $\begin{array}{l}\text { 4. Socialmedia posts lesen und } \\
\text { schreiben }\end{array}$ & & \\
\hline $\begin{array}{l}\text { 5. Nachrichten und Infoseiten (z.B. } \\
\text { Wetter, BahnApp) lesen }\end{array}$ & & \\
\hline
\end{tabular}

Sonstiges? 


\section{English-language translation:}

„As you are going to reads English-language texts in this experiment, I will now ask you a few questions about your language learning."

\section{A Language Learning History}

1. Since when have you been learning German?

Did you speak another language at home?

2. How many languages do you speak apart from German and how did you learn them?

\begin{tabular}{|l|l|}
\hline Language & $\begin{array}{l}\text { How learned (e.g. at school, within the family, } \\
\text { through language courses or stays abroad) }\end{array}$ \\
\hline & \\
\hline & \\
\hline & \\
\hline & \\
\hline
\end{tabular}

"Now I will ask you some questions specifically about how you learned English."

3. How old were you when you started learning English?

4. What was your English grade in your school-leaving examination?

$$
\text { o No idea }
$$

5. Have you ever stayed abroad in an English-speaking country?

Yes 0 No 0

How long was your stay?

6. How would you judge your own English language skills?

Response scale (shown to subjects):

\begin{tabular}{|l|l|l|l|l|} 
Not at all. & & & & $\begin{array}{l}\text { Like a native } \\
\text { speaker }\end{array}$ \\
\hline 1 & 2 & 3 & 4 & 5 \\
\hline
\end{tabular}

Language comprehension:

Speaking and Writing:

\section{B. Current English Use}

"To finish off I would like to ask how you use English in your free-time." 
7. Do you have friends or acquaintances with whom you speak English? Yes No

If yes: How frequently?

\begin{tabular}{|l|l|l|l|l|}
\hline $\begin{array}{l}\text { Irregularly } \\
\text { only, e.g. when } \\
\text { at holiday }\end{array}$ & $\begin{array}{l}\text { Less than } \\
\text { once a } \\
\text { month }\end{array}$ & $\begin{array}{l}\text { Less than } \\
\text { once a week }\end{array}$ & $\begin{array}{l}1-2 \text { times } \\
\text { per week }\end{array}$ & $\begin{array}{l}3 \text { or more } \\
\text { times per } \\
\text { week }\end{array}$ \\
\hline 1 & 2 & 3 & 4 & 5 \\
\hline
\end{tabular}

8. Think back to the last four weeks. How frequently have you used English fort he following activities, relative to German? Please indicate first how often you have engaged in this activity and then, in which language.

Response scale for how often (in general):

\begin{tabular}{|l|l|l|}
\hline Never & Sometimes & Often \\
\hline 1 & 2 & 3 \\
\hline
\end{tabular}

Response scale for how often in each language:

\begin{tabular}{|l|l|l|l|l|}
\hline $\begin{array}{l}\text { Always } \\
\text { in } \\
\text { German }\end{array}$ & $\begin{array}{l}\text { More often in } \\
\text { German than } \\
\text { in English }\end{array}$ & $\begin{array}{l}\text { Approximately as } \\
\text { often in German } \\
\text { as in English }\end{array}$ & $\begin{array}{l}\text { More often in } \\
\text { English than in } \\
\text { German }\end{array}$ & $\begin{array}{l}\text { Always in } \\
\text { Englisch }\end{array}$ \\
\hline 1 & 2 & 3 & 4 & 5 \\
\hline
\end{tabular}

No idea.

\begin{tabular}{|l|l|l|}
\hline & How often? & How in English or German? \\
\hline $\begin{array}{l}\text { 1. Watch Youtube videos or films and } \\
\text { series }\end{array}$ & & \\
\hline 2. Read books or papers & & \\
\hline 3. Listen to podcasts or the radio & & \\
\hline 4. Read and write ocialmedia posts & & \\
\hline $\begin{array}{l}\text { 5. Read news and info pages (e.g. } \\
\text { about the weather or train updates)? }\end{array}$ & & \\
\hline
\end{tabular}

Anything else? 


\section{Appendix B: Eye-tracking Stimuli}

Word difficult targets are underlined, inconsistency pre-target and target are in italics.

\section{Bullying}

A controversial computer game has just come out. In the game, players take on the role of a lonely / shunned student. They have to fight / resist bullies in the school by shooting / kicking them. Critics say the game supports / encourages violence with the players shooting bullies. The makers disagree and say / claim that the game is just a(n) funny / amusing look at school life.

\section{Angkor Thom}

The old / ancient city Angkor Thom used to be the capital of an Empire in present-day Cambodia. The city is the site of huge / mountainous stone faces/gates. Tourists are always amazed / dazzled at the size of these stone faces which are almost / practically overgrown by the jungle. To see it all can take many / innumerable days.

3. Counting animals

To know / identify how many animals live in an area, you can count them within a smaller area and multiply the results. Large animals can simply / readily be counted, but smaller animals such as mice / worms must be trapped. These traps are filled / supplied with food that mice like to eat / consume so that they walk / wander into the trap. Once they are trapped, they can be counted easily.

4. Musician

Juan Luis Guerra is a singer whose work covers / incorporates many musical strands jazz, salsa, gospel, and more. Born in 1957, Guerra went to / enrolled at university to study literature / philosophy. However, he then soon chose / resolved to study music instead of literature, luckily for us all. He would never / hardly have been as good / talented a writer as he was a musician!

\section{Reality TV}

Some people say that the name 'reality TV' is wrong / inaccurate because producers always / invariably select the people / games they show. Through this, producers make / fabricate a world filled with people they want to show. Mark Burnett, maker / inventor of many / multiple reality shows, says: 'I tell good stories, but it isn't reality TV. It really is unscripted drama.'

6. Swimsuits

In the 2008 Beijing Summer Olympics, swimmers set 25 new world records thanks to new / groundbreaking swimsuits. These new swimsuits helped / improved the water/ blood flow for swimmers. However, Olympics officials decided / determined that this improved water flow was an unfair / unjust advantage, forbidding / excluding the swimsuits for future Olympics.

7. Biofuels

A new / damning report has voiced / expressed concerns about biofuels as a solution for global warming. Soya/Corn is often / increasingly used as a biofuel. The resulting level of soya production might have dangerous / alarming side effects. For example, it could add to the destruction / devastation of rain forests.

8. Snakes 
The brown tree snake was brought to Guam after World War II. Since then, its population has grown / expanded. The local government is now trying to cut / reduce their numbers by dropping poisoned dead mice/ birds into the jungle. They hope / anticipate the snakes will eat these mice and die of the poison. It is important/ imperative to get rid of these snakes because they kill many local animals / mammals.

9. Dogs in adverts

In the 1990s, Taco Bell had an advert with / featuring a dog that said / yapped 'I want Taco Bell!'. People loved the talking dog with its white/ black fur. Soon, these dogs became popular / fashionable pets, particularly those with white fur like the dog in the ad. But people found quickly / rapidly that these dogs don't make perfect pets. Sadly / Regrettably, many families gave them away.

10. Language in hospitals

In the US, people speak many different languages, which can make / render using hospitals difficult / challenging. In some states, many people speak only Spanish/ Russian. These states have thus written / prepared some information in hospitals in Spanish to help people communicate. But / Regrettably, some Americans would want / prefer to see only English in hospitals. Everyone would need to learn English or miss out.

11. Damaged cities

Recently, the Rockaways in New York were destroyed by Hurricane Sandy. New York paid / expended millions of dollars just / merely rebuilding the beaches / streets. The government also / moreover rebuilt people's homes which, alongside rebuilding the beaches, became very / exceedingly expensive. Other towns have chosen to move / relocate rather than rebuild. For example, the town Newtok was flooded and people decided to move to a town 9 miles away.

12. Animal testing

Animals are used / utilised by scientists seeking cures for disease. They are also / moreover used by companies to test make-up / shampoo. Animals share many genes with humans and testing / trialling the new make-up on animals first can protect humans from possibly / potentially harmful side effects. However, many people don't buy / purchase products tested on animals because they find animal testing cruel.

13. Typewriters

Throughout most of the 20th century, people used typewriters to make their documents look / appear more formal. Back then, it was common to write / compose drafts in handwriting first before typing up a poem/letter. Making only one mistake meant having to rewrite the whole / entire poem, so accuracy and precision / exactitude were important/indispensable. But this took a long time.

14. Computer programme

Who wrote the first computer programme?

Ada Lovelace was taught / instructed by Charles Babbage, who first had the idea for a computer. Ada found / invented a method to use the new computer for maths / music as well. Although her new / novel method is not used for maths any longer today / nowadays, it has since been remembered / recognized as the world's first computer programme. 
15. The Oakland A's

In 2002, the baseball team Oakland A's broke the record for most games won in a row. Many think / surmise that this was only possible / feasible thanks the top salaries / training that the Oakland A's offered their players. With these large / generous salaries, they got / attracted many famous players. Probably / Presumably, the Oakland A's were successful because they just bought up the best talents.

16. Mind reading

Scientists have studied / investigated changes in the brain when people think about different / dissimilar sports / songs. They measured / surveyed brain activities of people who thought of different sports such as dancing or swimming. In this study, the scientists found / uncovered that you can know / deduce from the brain activity which activity people were thinking of. So in a way, they read people's minds!

17. Learning languages

To judge / estimate how difficult a language will be to learn, you can check / assess how similar your first language is to the other language. For example / instance, a speaker of Spanish/English tends to find Chinese rather hard / laborious. The reason is that Spanish is very / immensely different to Chinese. The greater the differences, the harder it will be.

18. Man Booker Prize

Every year, the Man Booker Prize is given / awarded to a book / novel by a panel of judges. These judges are chosen so that they come from different countries / professions. For example, last / previous year's judges came from such very different countries as China, England, and Norway. However, once the judges are chosen / elected, they are free to reach their own decision / verdict.

19. Energy ratings

Energy ratings say / detail how much energy a building uses for heating. Today / Nowadays, all UK schools / hospitals need energy ratings for their building. But /

Regrettably, a lot of schools are in old buildings that are not energy efficient at all. This makes / renders it problematic for them to get good / satisfactory energy ratings.

20. Junk food

Many teenagers know / apprehend that eating junk food is unhealthy because they have / contain too much sugar / salt, yet teenagers continue to eat them regularly / routinely. Eating all this sugar strongly affects / impacts young people's health. As a result, diabetes rates have been rising among teenagers, so the effects are truly not small / minor.

21. Modern farming techniques

Since the 1960s, people have improved / enhanced their harvests by using / adopting modern farming techniques. As a result, wheat/rice harvests have doubled internationally. However, global warming has made growing / cultivating wheat more difficult / troublesome again through sudden / recurrent floods and dry periods. To cope, farmers now try to make their seeds more resistant to extreme weather.

22. Stable ecosystems 
Normally / Typically, the numbers of a species remain fairly stable / immutable within a stable ecosystem. This has been studied in Canadian forests where researchers counted the numbers of wild cats / dogs over many years. Some years / decades, the number of Canadian wild cats increased or decreased due to less water or sunlight. Overall / Globally, however, their numbers stayed / remained the same.

\section{Pills and exams}

One day, taking pills that improve one's intelligence might be as normal / ordinary as drinking coffee. There already is a sleeping pill that helps / enables one to remember songs / numbers better. This sleeping pill raises a serious / profound question: can remembering songs better be an unfair / undeserved advantage in some exams? People already take vitamins to help them focus / thrive in exams, so the answer won't be simple.

24. Teenagers' clothes

Many schools are making / formulating rules about what their students should wear. Some US schools have now banned / opposed all t-shirts with pictures / language on them. The reason is that these schools believe / surmise that pictures on t-shirts distract their students. However, many of their students believe / argue that this rule is absurd / exaggerated.

25. School days

Some US states want / propose to introduce longer / extended school days. So far, American students used to spend up to $30 \%$ less time at school than students in other countries. The performance of American students in maths / music suggests this isn't enough / sufficient. In 2012, American students had worse maths grades / outcomes than students in 33 other rich / industrialised countries.

26. Vegetarian

More and more people decide / resolve to eat vegetarian because they want to avoid / circumvent health / climate problems. They think / assert that by eating vegetarian, they will avoid health problems linked to eating meat, such as diabetes. However, other people say / presume that meat is healthy because it is a good / nutritious source of protein.

27. Power stations

Power stations run / operate continuously and are very good / reliable sources of energy. Many power stations run on fossil / nuclear fuels. When more / additional power is needed, usually one of these fossil power stations is used because they can provide / generate electricity quickly / instantly, different from wind or sun power that rely on sunny or windy weather.

28. Mars exploration rovers In 2003, the NASA sent two rovers to Mars to test / inspect its geography. Before their launch, engineers made / assembled a model of Mars to teach the rovers to avoid the rocks / sand on Mars. Thanks to this, the rovers successfully avoided / circumvented all rocks while they were exploring / investigating Mars. They explored it for days and collected a lot / plethora of useful information.

29. Solar panels 
Carver School has decided to provide / generate its own electricity by getting / installing solar panels. However, these solar panels will be put where there is currently a kitchen / library for students. Many students are really / tremendously sad to lose their kitchen and say / demand that the solar panels should be put / installed at other schools instead of theirs.

\section{Pigeons}

Liverpool city council wants / envisages to clear the city of pigeons with the help of ten robotic birds. The mechanical birds will sit / perch on roofs / trees and make loud noises to scare / frighten the pigeons. From these roofs, they will later be moved around in the city centre. Liverpool city council hope / presume that this will chase the pigeons out of the whole / entire city centre.

\section{Deaf children}

Before 1977, deaf children in Nicaragua were not allowed / tolerated at school because everyone thought / conjectured that these children couldn't understand the school subject science / history anyways. But / Notwithstanding, deaf children started speaking with gestures and studied science, different from what people had thought / reckoned. Finally, the Nicaraguan government built / erected special schools for deaf students.

\section{Goal of education}

Some people think / postulate that the goal of education is to prepare students for work. They want students to learn / acquire particular skills, such as reading / carpentry. They think that if students learn to be good / proficient at reading, they are more likely to succeed / thrive on the job market. Other people believe / surmise that schools should teach students to think critically instead.

33. Selling lemonade

Selling lemonade has a(n) long / extensive history in the US. The first lemonade stand was in New York City in 1879. A shopkeeper decided / organised to sell cold lemonade to thirsty children/women on the street. That day, he managed / succeeded to sell these children many / numerous bottles of lemonade and other shopkeepers followed his example. By 1900, selling lemonade became very popular / customary.

34. Identity

People have always / eternally wondered / pondered: what makes us who we are? Our genes / career have one of the biggest / profoundest impacts. This is because our genes hold / contain information about our own unique design. They help decide / determine many features, such as our eye colour or which hand we use to write.

\section{Legalising drugs}

Buying and selling alcohol was forbidden / prohibited in the US from 1920 to 1933 but is legal today. Some people have now suggested / proposed that similarly, cocaine / hashish_could be legalised. They think / theorise that it'd be safer if cocaine were legal because the police could focus / concentrate on more serious / consequential crimes.

36. Child workers 
Child workers have been found working in an Indian factory for long / prolonged hours of tiring work. The company said they were unaware / oblivious that their clothes/ phones were produced by children. They promised / announced to not produce their clothes in this place / location anymore until they had changed / modified their production conditions.

37. Water consumption

Water consumption has risen globally. A major reason is that the world's population is growing / expanding all the time. More people means / entails that a lot of water is needed for washing / cooking almost every day. This is because people need / require water for washing themselves frequently / periodically so they can avoid / prevent getting sick, which easily happens with poor hygiene.

\section{Certificates}

There is a new certificate for wood companies that meet ecological standards. Many companies are becoming more ecologically friendly to receive / obtain this certificate. However, it is unlikely / improbable that wood companies in Finland / England will do the same. The reason / assumption is that consumers in Finland don't place much trust / faith in certificates, so having the certificate would not help / benefit these companies.

39. Electricity

Producing / generating electricity always requires some kind of energy resource. To save the environment, many people like / prefer to use renewable energy resources, one of which is wind / sun power. With many people trying / endeavouring to give up fossil fuels, wind power is becoming more/ increasingly important / consequential for the electricity production of tomorrow.

40. Agriculture in Africa

Agriculture in Africa started before 3000 b.c. With the drying up of what is now / nowadays the Sahara Desert, many people moved south and built / erected larger towns near rivers / forests where wild animals lived. Possibly / Presumably, agriculture started thanks to these rivers over which travellers / voyagers arrived from the Near East and told / instructed the town people about agriculture.

41. Barbie

Many think / affirm that Barbie is a dangerous role model. One example is Cindy Jackson who decided to have / undergo surgery to make her nose/ legs like Barbie's. Most women wouldn't do / undertake the same for Barbie's nose as Cindy Jackson. But it is rarely explained / delineated to young girls that Barbie's body is so different / artificial that in real life, she couldn't even walk.

42. Turtles

Eastern box turtles are great / enchanting pets. These turtles don't need any special / overpriced food: just feed them vegetables and meat / fruits. Some days, they are really / exceptionally active and eat even more meat than they normally / habitually would. An eastern box turtle can live for up to 100 years, so it can be a friend / companion for life!

43. Taliban 
The Taliban is an armed group that took control of cities in Pakistan where they applied / imposed strict rules. For example, they did not allow / tolerate any dancing / schooling for girls at all. This was hard because people loved / appreciated dancing at social festivals. The Taliban strongly / severely limited everyone's rights even further by stopping / banning music as well. Living under the Taliban was certainly not easy.

44. Puritans

The Puritans were a religious group who disagreed / quarrelled with the Church of England. The King responded by taking away many of the Puritans' rights / freedoms and by issuing prison / death sentences against his critics / doubters. However, these critics did not let their prison sentences stop them from writing books that challenged / denounced the church. By 1630, however, the Puritans' situation worsened / aggravated and many left England.

\section{Statue}

At a train station in Tokyo, there is a large / colossal statue of the dog Hachiko. The reason behind it is that every day, Hachiko followed / accompanied his owner, a teacher / cleaner, to the station and awaited his return / arrival. One day, the teacher died at work before he could return to Hachiko. Hachiko continued to wait / linger at the station every day. After his death, people built / erected a statue of him.

\section{Books}

Each year, people try / strive to keep certain books out of schools because they want to protect / safeguard young readers from stories dealing with racism / murder. These people think / assert that if a book tells stories about racism, it will give young people wrong / immoral ideas. But other people think / maintain that these books help young people understand difficulties in their own lives.

47. Models

Models can help with making big / pivotal decisions. For example, let's imagine that an engineer is planning / drafting a bridge/ tunnel. He can't just / merely build one to find out if the bridge will be stable / durable enough to carry cars. Instead, the engineer can make / fabricate a model and put weights on to simulate the load of cars driving over it.

48. Cameras

The police in Baltimore are trying / striving to reduce crime rates by checking / surveying images from private cameras placed in people's offices / gardens. However, people dislike / oppose the use of these private cameras in offices because they have already had bad / unpleasant experiences. Once, a woman was filmed by a hidden camera while she changed her clothes to go to the gym! You can imagine / envisage how she felt. 


\section{Tables}

Table 1: English language learning history and use and raw scores on English language measures in our sample.

\begin{tabular}{lll} 
Mean (SD) & & Range \\
\cline { 1 - 1 } $8 ; 06(1 ; 05)$ & & $3 ; 00-11 ; 00$ \\
$7.6(10.7)$ & & $0.5-60$
\end{tabular}

Current English language use

Watching online videos, series, or films

$3.3(1.1) \quad 1-5$

Reading papers or books

$2.6(1.4) \quad 0-5$

Social media use

$2.6(1.6) \quad 0-5$

Reading news or informational websites

$2.0(0.8) \quad 0-4$

Listening to podcasts or radio programs

$0-5$

English language measures

Single word reading $94-163$

Vocabulary size $73(11)$

$51-98$

'Months spent in English-speaking country' only reported for subset of participants who reported any stay of more than one week. 'Current English language use' scores range from 0-5, where 0 indicates either not using a medium or never using it in English, and 5 indicates using a medium only in English. 
Table 2: Example story and question.

A new / damning report has voiced / expressed concerns about biofuels as a solution for global warming. Soya / Corn is often / increasingly used as a biofuel. The resulting level of soya production might have dangerous / alarming side effects. For example, it could add to the destruction / devastation of rain forests.

Recall prompt: Biofuels

Word difficult targets are underlined, inconsistency pre-target and target are in italics. 
Table 3: Matching of easy and difficult word processing difficulty manipulated words.

\begin{tabular}{|c|c|c|c|}
\hline & Easy & Difficult & $t$-test results \\
\hline Frequency in & $5.4(0.8)$ & $3.6(0.7)$ & $t(421.1)=24.7$ \\
\hline SUBTLEX-UK & Range: $3.2-6.9$ & Range: $1.3-4.9$ & $p<0001$ \\
\hline Frequency in & $5.3(0.7)$ & $4.0(0.6)$ & $t(417.5)=21.6$ \\
\hline $\mathrm{BNC}$ & Range: $3.0-6.8$ & Range: $2.1-5.2$ & $p<0001$ \\
\hline \multirow[t]{2}{*}{ Letter lengths } & $5.2(1.7)$ & $7.9(2.0)$ & $t(407.9)=-$ \\
\hline & & & $15.3, p<.0001$ \\
\hline
\end{tabular}

Values are means with standard deviations in brackets, frequency is Zipf-Frequency $(\log$-frequency +3$)$. 
Table 4: Observed means for reading of inconsistency targets (e.g. soya) by inconsistency and word processing difficulty.

\begin{tabular}{|c|c|c|c|c|c|c|c|c|c|c|c|}
\hline & \multicolumn{2}{|c|}{$\begin{array}{c}\text { Gaze } \\
\text { duration }\end{array}$} & \multicolumn{2}{|c|}{$\begin{array}{l}\text { Go-past } \\
\text { duration }\end{array}$} & \multicolumn{2}{|c|}{$\begin{array}{c}\text { Regression in } \\
\text { probability }\end{array}$} & \multicolumn{2}{|c|}{$\begin{array}{l}\text { Rereading } \\
\text { probability }\end{array}$} & \multicolumn{2}{|c|}{$\begin{array}{l}\text { Rereading } \\
\text { time }\end{array}$} & Total time \\
\hline & Cons & Inc & Cons & Inc & Cons & Inc & Cons & Inc & Cons & Inc & Cons \\
\hline Easy & 264 & 286 & 328 & 394 & 0.15 & 0.27 & 0.47 & 0.69 & 220 & 393 & 493 \\
\hline words & (123) & (134) & (203) & $(265)$ & $(0.36)$ & $(0.45)$ & $(0.50)$ & $(0.46)$ & (371) & $(516)$ & $(397)(468)$ \\
\hline Difficult & 268 & 287 & 339 & 366 & 0.21 & 0.33 & 0.55 & 0.68 & 226 & 403 & 504 \\
\hline words & (118) & (123) & (213) & (229) & $(0.41)$ & $(0.47)$ & $(0.50)$ & $(0.47)$ & (328) & $(519)$ & $(358)(473)$ \\
\hline
\end{tabular}

Cons $=$ consistent, Inc $=$ inconsistent. 
Table 5: Models predicting reading of inconsistency targets (e.g. soya).

\begin{tabular}{|c|c|c|c|c|c|c|}
\hline & $\begin{array}{c}\text { Gaze } \\
\text { duration }\end{array}$ & $\begin{array}{l}\text { Go-past } \\
\text { duration }\end{array}$ & $\begin{array}{l}\text { Regression } \\
\text { in } \\
\text { probability }\end{array}$ & $\begin{array}{l}\text { Rereading } \\
\text { probability }\end{array}$ & $\begin{array}{c}\text { Rereading } \\
\text { time }\end{array}$ & $\begin{array}{l}\text { Total } \\
\text { time }\end{array}$ \\
\hline Word processing & 0.01 & 0.00 & 1.18 & 1.09 & 0.09 & 0.02 \\
\hline difficulty & $(0.02)$ & $(0.01)$ & $(0.09)$ & $(0.05)$ & $(0.06)$ & $(0.02)$ \\
\hline \multirow[t]{3}{*}{ Inconsistency } & $0.04^{* * *}$ & $0.06^{* * *}$ & $1.46^{* * *}$ & $1.53^{* * *}$ & $0.56^{* * *}$ & 0.14 \\
\hline & $(0.01)$ & $(0.01)$ & $(0.07)$ & $(0.06)$ & $(0.08)$ & $* * *$ \\
\hline & & & & & & $(0.02)$ \\
\hline Word processing & -0.00 & $-0.02^{*}$ & 0.97 & $0.89^{*}$ & $-0.12^{*}$ & -0.01 \\
\hline difficulty X & $(0.01)$ & $(0.01)$ & $(0.05)$ & $(0.05)$ & $(0.05)$ & $(0.01)$ \\
\hline Inconsistency & & & & & & \\
\hline
\end{tabular}

$\overline{\text { Estimates are beta estimates with standard error in brackets. } * p<0.05 \quad * * p<0.01 \quad * * * p<0.001}$ 
Table 6: Observed means for reading of whole text and of word processing difficulty manipulated words (e.g. dangerous or alarming) by inconsistency and word processing difficulty.

\begin{tabular}{|c|c|c|c|c|c|c|c|c|c|c|c|}
\hline & \multicolumn{8}{|c|}{ Word processing difficulty manipulated words } & \multirow[b]{2}{*}{$\begin{array}{l}\text { Total } \\
\text { time }\end{array}$} & \multicolumn{2}{|c|}{ Whole text reading } \\
\hline & \multicolumn{2}{|c|}{$\begin{array}{c}\text { Gaze } \\
\text { duration }\end{array}$} & \multicolumn{2}{|c|}{$\begin{array}{l}\text { Go-past } \\
\text { duration }\end{array}$} & \multicolumn{2}{|c|}{$\begin{array}{l}\text { Regression } \\
\text { in } \\
\text { probability }\end{array}$} & $\begin{array}{l}\text { Rereading } \\
\text { probability }\end{array}$ & $\begin{array}{c}\text { Rereading } \\
\text { time }\end{array}$ & & \multicolumn{2}{|c|}{$\begin{array}{c}\text { First-pass } \text { Second- } \\
\text { pass }\end{array}$} \\
\hline & Cons & Inc & Cons & Inc & Cons & Inc & Cons Inc & Cons Inc & Cons & \multicolumn{2}{|c|}{ Inc Cons Inc Cons Inc } \\
\hline Easy & 266 & 264 & 395 & 399 & 0.22 & 0.24 & $0.51 \quad 0.59$ & $226 \quad 274$ & 507 & $\begin{array}{ll}547 & 12.2\end{array}$ & $\begin{array}{lll}12.5 & 9.5 & 10.9\end{array}$ \\
\hline words & (124) & (125) & (391) & (399) & $(0.41)$ & $(0.43)$ & $(0.50)(0.49)$ & $(346)(395)$ & (386) & $(425)(3.2)$ & $(3.2)(7.1)(7.7)$ \\
\hline Difficult & 340 & 345 & 574 & 596 & 0.31 & 0.35 & $0.64 \quad 0.69$ & $447 \quad 509$ & 841 & $897 \quad 13.1$ & 13.211 .412 .7 \\
\hline words & $(165)$ & (167) & $(480)$ & $(511)$ & $(0.46)$ & $(0.48)$ & $(0.48)(0.46)$ & $(598)(629)$ & $(615)$ & $(643)(3.2)$ & $(3.2)(7.9)(7.9)$ \\
\hline
\end{tabular}


Table 7: Models predicting reading of whole text and of word processing difficulty manipulated words (e.g. dangerous or alarming).

Word processing difficulty manipulated words

Whole text

\begin{tabular}{ccccccccc}
\hline Gaze & Go-past & Regression & Rereading & Rereadi & Total & First- & Second- \\
duration & duration & in & probability & probability & ng time & time & pass & pass \\
& & & & & & time & time
\end{tabular}

Word

$0.13^{* * *} \quad 0.19^{* * *}$

$1.31^{* * *}$

$1.34^{* * * *}$

$0.45^{\text {*** }}$

$0.24^{* * * *}$

0.03

$0.11^{* * *}$

processing

$(0.01) \quad(0.01) \quad(0.04)$

(0.03)

(0.04) (0.01)

difficulty

Inconsistency

$\begin{array}{ccc}0.00 & 0.01 & 1.08^{* * *} \\ (0.00) & (0.01) & (0.02)\end{array}$

$1.17^{* * *}$

$0.20^{* * *}$

$0.04^{* * *}$

$(0.00)$

(0.00)

(0.01)

(0.02)

(0.03) (0.01)

0.01

$0.08^{* * *}$

****

(0.02)

(0.00)

Word

$0.00 \quad 0.01$

1.01

0.97

$-0.03$

$-0.00$

$-0.00$

$-0.00$

processing

(0.00) (0.00)

(0.02)

(0.02)

(0.02)

(0.01)

(0.00)

(0.01)

difficulty $\mathrm{X}$

Inconsistency

Estimates are beta estimates with standard error in brackets. $* p<0.05 \quad * * p<0.01 \quad * * * p<0.001$ 


\section{List of Figures}

Figure 1: Main effect of inconsistency on the reading of inconsistency target words. Reading times are model means in ms.
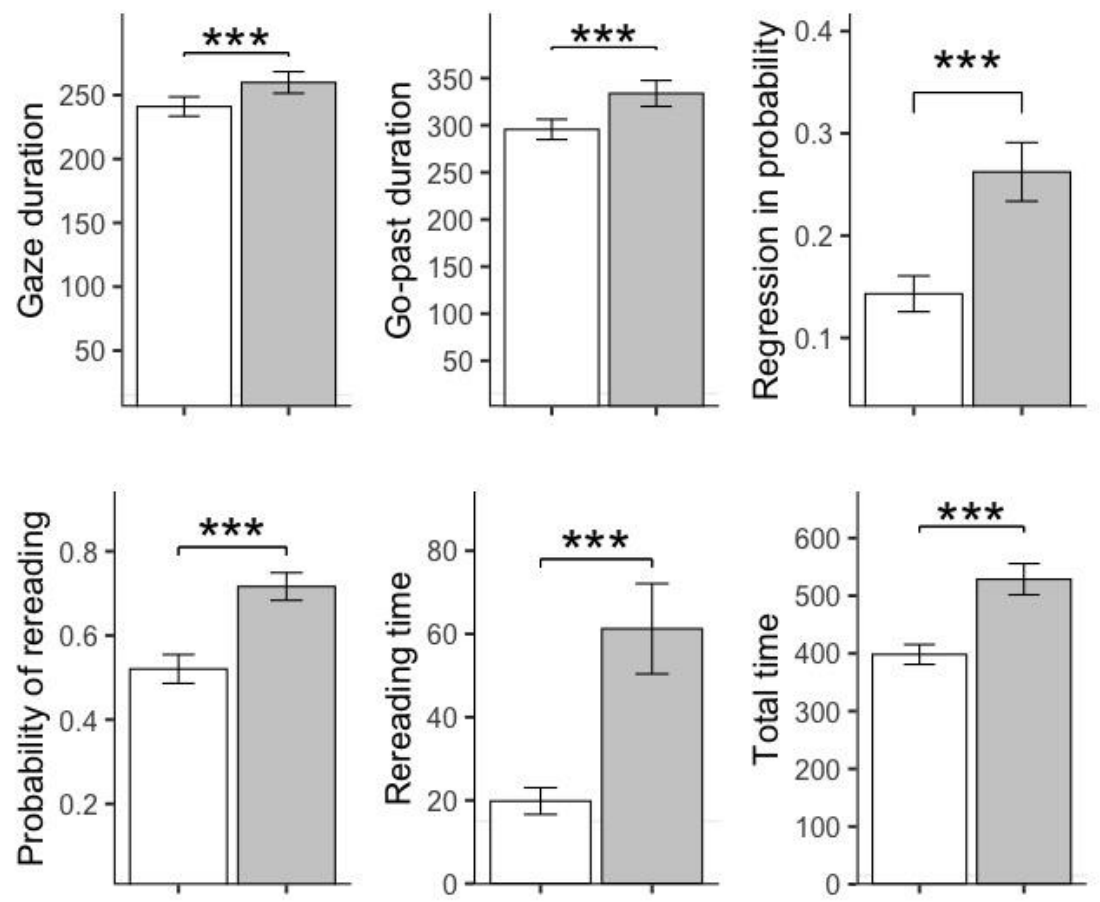

Figure 2: Word processing difficulty main effects on difficulty manipulated targets. Reading times are model means in ms.
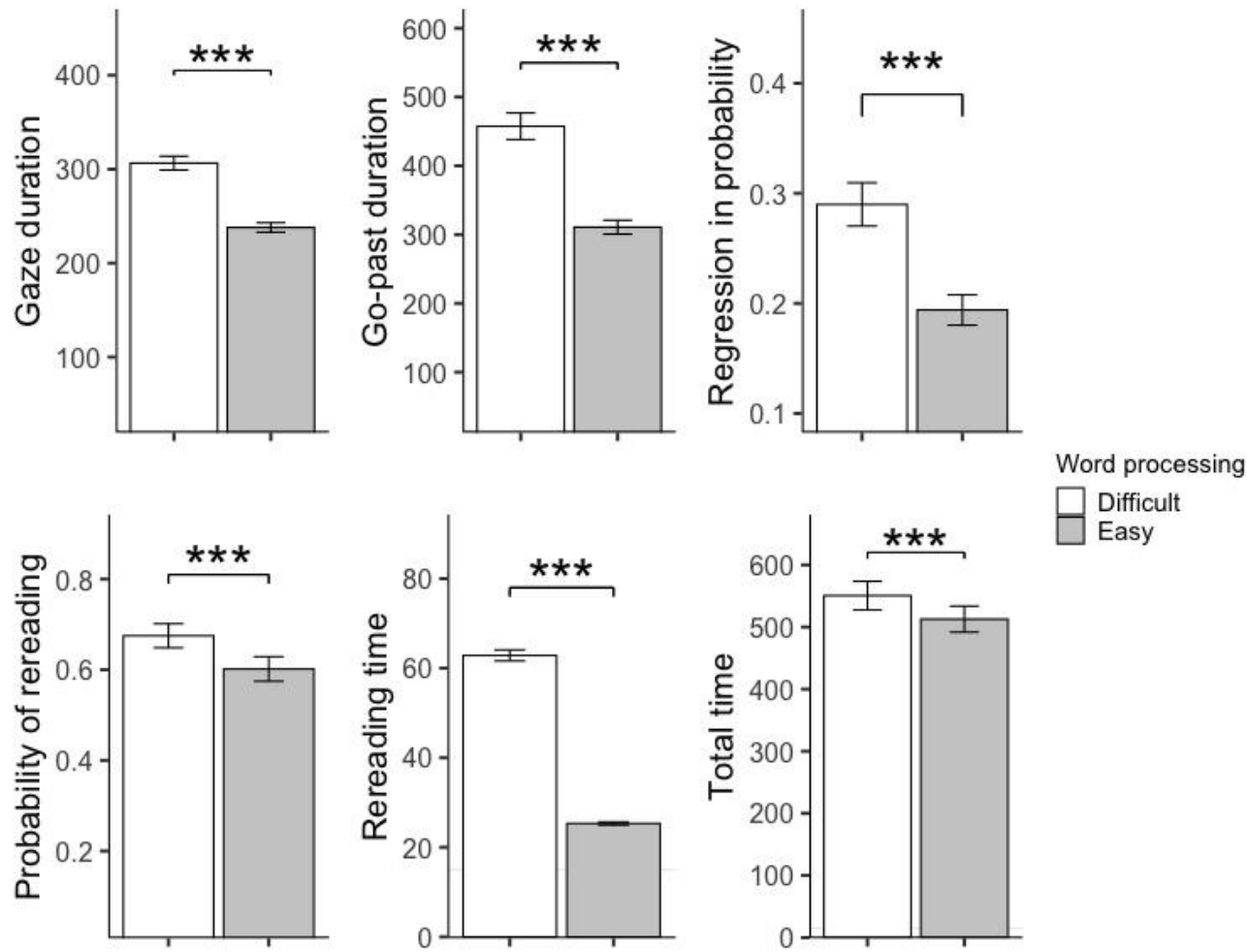
Figure 3: Interaction between word processing difficulty and inconsistency on the rereading of target words.Reading times are model means in $\mathrm{ms}$.
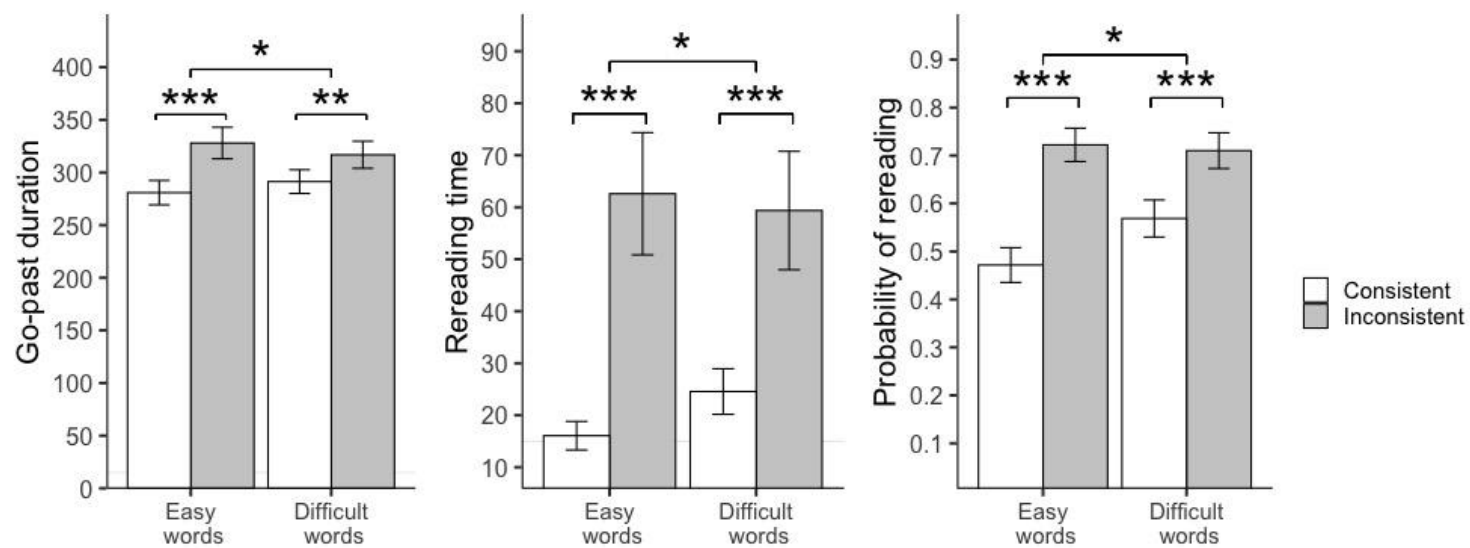